УДК 697.94.(075)

В.Й. Лабай凶

Національний університет «Львівська політехніка», вул. Ст. Бандери, 12, Львів, 79013

\e-mail: wlabay@i.ua

\title{
ДОСЛІДЖЕННЯ ЕКСЕРГОЕФЕКТИВНОСТІ ТА ШЛЯХІВ ЕНЕРГОЗБЕРЕЖЕННЯ СИСТЕМИ КОНДИЦІЮВАННЯ ПОВІТРЯ ОПЕРАЦІЙНИХ ЧИСТИХ КІМНАТ
}

\begin{abstract}
У статті наведений аналіз ексергоефективності впровадженої центральної прямотечійної системи кондиціювання повітря (СКП) операчійних чистих кімнат, отриманий на ї̈ інноваційній математичній дослідницькій моделі залежно від різних факторів, що впливають на ї̈ роботу, та запропоновані шляхи енергозбереження для иієї СКП. Встановлено, щуо найбільший вплив на ексергетичний ККД цієї системи кондиціювання мають різниця температур між внутрішнім $i$ припливним повітрям у приміщенні, температура внутрішнього повітря, залежна від температури зовнішнього повітря, та коефіцієнт трансформації EER прийнятої холодильної машини СКП.

Ключові слова: Системи кондиціювання повітря - Чисті кімнати - Ексергетичний баланс - Ексергетична ефективність - Енергозбереження
\end{abstract}

\section{В.И. Лабай, Д.И. Гарасылм}

Национальный университет «Львовская политехника», ул. Ст. Бандеры, 12, Львов, 79013

\section{ИССЛЕДОВАНИЕ ЭКСЕРГОЭФФЕКТИВНОСТИ И ПУТЕЙ ЭНЕРГОСБЕРЕЖЕНИЯ СИСТЕМЫ КОНДИЦИОНИРОВАНИЯ ВОЗДУХА ОПЕРАЦИОННЫХ ЧИСТЫХ КОМНАТ}

В статье приведен анализ эксергоэффективности внедренной центральной прямоточной системы кондиционирования воздуха (CKB) операционных чистых комнат, полученный на ее инновационной математической исследовательской модели в зависимости от разных факторов, какие влияют на ее работу, и предложены пути энергосбережения для этой СКВ. Определено, что наибольшее влияние на эксергетический КПД этой системь кондиционирования имеют разность температур между внутренним и приточным воздухом, температура внутреннего воздуха, зависящая от температуры наружного воздуха, и коэффиичиент трансформации EER принятой холодильной машины СКВ.

ключевые слова: Системь кондиционирования воздуха - Чистые комнаты Эксергетический баланс - Эксергетическая эффективность - Энергосбережение

DOI: $10.15673 / 0453-8307.4 / 2015.48627$

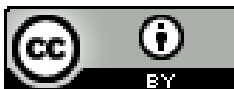

\section{I. ВСТУП}

Сьогодні для України проблема заощадження енергетичних ресурсів особливо актуальна в умовах ринкової економіки за обмежених ресурсів основних енергоносіїв - нафти та газу.

Тому в останні десятиріччя за кордоном 3 метою заощадження енергетичних ресурсів ведуться фундаментальні дослідження діяльності ряду галузей, виробництв і технологій із позицій ексергетичної методології [6-10, 12, 13, 15, 16]. Ця методологія була обгрунтована у роботах Р.К. Клаузіуса, Дж.В. Гіббса, Ж. Гюі, А. Стодоли, Я. Шаргута та Р. Петели. Величина, що визначає придатність до дії (працездатність) ресурсів речовини та енергії, була названа ексергією, а функції, що визначають іiі значення, - ексергетичними. Термін «ексергія», що визначає придатність до дії (працездатність) ресурсів речовини та енергії, був введений у 1956 році.
Потоки енергії та ексергії завжди співіснують. Вони можуть дорівнювати один одному, якщо йдеться про потоки механічної чи електричної енергії, і дуже сильно відрізняються в потоках теплоти. Ексергія не тільки кількісно характеризує енергію будь-якого виду, а й дозволяє оцінити іiі якісний стан. Вона визначає перетворюваність, придатність енергії для технічного використання в будь-яких заданих умовах.

Оскільки ексергія є єдиною мірою працездатності, придатності енергетичних ресурсів, ії застосування дає змогу дати об'єктивну оцінку енергетичних ресурсів будь-якого виду. Отже, ексергія $є$ деякою універсальною мірою енергетичних ресурсів. А ексергетичний баланс, на підставі якого встановлюється масштаб використання енергетичних ресурсів, вказує на можливість підвищення коефіцієнта корисної дії (ККД) процесу.

Існує чимало прикладів успішного застосування ексергетичної методології за техніко-економічної оптимізації в промисловості, особливо в 
енергоємних галузях. Незворотну втрату ексергії можна зменшити завдяки поєднанню як теплових процесів, так і технологічних та теплових процесів.

Нині вартісні оцінки не можуть служити єдиною мірою ефективності енергетичного обладнання, які переробляють енергоресурси. Ексергія $є$ фізичним, а не економічним критерієм і визначає незалежність цього параметра від кон'юнктурних коливань цін. В той самий час вартісні показники не дозволяють здійснити довгострокове прогнозування. Визначати мінімум необхідно не грошовими витратами, а витратами ексергії на одиницю виданої теплоти. Непридатність тільки грошових критеріїв очевидна.

У деяких провідних європейських країнах і в США ексергетичний аналіз запровадили як обов'язкову складову розроблюваних проектів, а також планів модернізації виробництв.

У сучасних технологіях, пов'язаних з перстворенням енергіï, а саме у системах кондиціювання повітря, важливе місце займають обладнання i процеси, об'єктивна оцінка ступеня енергетичної досконалості яких може бути встановлена тільки на основі аналізу їх ексергоефективності.

Отже, зменшення затрат енергії, споживаної системами кондиціювання повітря, диктує необхідність їх оптимізації, що найповніше може бути досягнуто на основі ексергетичного аналізу, який враховує не тільки кількість, але й якість затраченої енергіï [7, 8, 11-20].

\section{II. ОПИСАННЯ ОБ'ЄКТУ АНАЛІЗУ ТА ЙОГО РОБОТИ}

Метою кондиціювання повітря є підтримання у деякому обмеженому просторі (у даному випадку у чистому приміщенні) певних параметрів повітря. Звичайно регулюванню підлягає температуpa $t_{\text {в }}$ і відносна вологість $\varphi_{\text {в }}$ повітря, а у чистих приміщеннях це ще й концентрація пилинок $x_{\mathrm{B}} \mathrm{y}$ повітрі [1-5].

Температуру внутрішнього повітря у приміщенні $t_{\text {в }}$ в теплий період року (ТПР) обмежували залежно від температури зовнішнього повітря так: коли $t_{3} \leq 30^{\circ} \mathrm{C}, t_{\mathrm{B}}=20 \ldots 25^{\circ} \mathrm{C}$

$$
t_{\mathrm{B}}=20+0,63 \cdot\left(t_{3}-22\right),{ }^{\circ} \mathrm{C},
$$

коли $t_{3}>30^{\circ} \mathrm{C}, t_{\mathrm{B}} \geq 26^{\circ} \mathrm{C}$

$$
t_{\mathrm{B}}=25+0,4\left(t_{3}-30\right),{ }^{\circ} \mathrm{C},
$$

Для операційних чистих кімнат нами застосовано центральну прямотечійну СКП, схематично зображену на рисунку 1. Отже, у теплий період року (ТПР) зовнішнє повітря через клапан 11 забирається центральним кондиціонером, очищається у фільтрі 10, далі проходить через повітрона грівник 9, охолоджується та осушується за політропою у повітроохолоднику 8, сепарується у краплевловнику 7, а відтак вентиляторним агрегаттом 6 подається через фільтр кондиціонера 5 і фільтри 3 на вході у чисті операційні кімнати. Видаляється відпрацьоване повітря 3 операційних чистих приміщень 3 верхньої $\mathrm{i}$ нижньої $30 \mathrm{H}$ витяжною установкою через ії клапан 17 витяжним вентилятором 18.

Розглянемо роботу даної СКП у ТПР, коли температура $t_{\mathrm{B}}<t_{3}$. На рисунку 2 наведена у системі координат $I, d$ послідовність зміни параметрів повітря, яке проходить через різне обладнання впровадженої центральної прямотечійної системи кондиціювання повітря для операційних чистих кімнат у ТПР за різних параметрів зовнішнього повітря. У дослідженнях прийнято масову продуктивність СКП, пораховану за необхідною кратністю повітрообміну, $G=4300$ кг/год, параметри зовнішнього повітря змінювались у межах: температура $t_{3}=30-40^{\circ} \mathrm{C}$; відносна вологість $\varphi_{3}=44-36 \%$ (відповідно, питома ентальпія вологовміст $d_{3}=11,7-16,8$ г/кг; $I_{3}=60,1-83,4$ кДж/кг), барометричний тиск $p_{3}=1010$ гПа; параметри внутрішнього повітря відповідно $-t_{\text {в }}=$ $25-29^{\circ} \mathrm{C} ; \varphi_{\mathrm{B}}=54-64 \%$ (відповідно, $d_{\text {в }}=10,8-16,3$ г/кг; $I_{\text {в }}=52,6-70,8$ кДж/кг); різниця температур між внутрішнім і припливним повітрям залежно від теплонадлишків у чистому приміщенні, а також температури зовнішнього повітря $\Delta t_{\Pi}=t_{\mathrm{B}}-t_{\Pi}=9,0-4,0^{\circ} \mathrm{C} ;$ кутовий коефіцієнт процесу асиміляції тепло- і вологонадлишків у чистих приміщеннях припливним повітрям 3 кондиціонера $\varepsilon=27058-9711$ кДж/кг; початкова температура холодоносія (40\% розчину пропіленгліколю) для повітроохолодника: $t_{\mathrm{B}_{\Pi}}=9,5-15,5^{\circ} \mathrm{C}$.

Послідовність змін, які відбуваються з вологим повітрям, що проходить через різне обладнання впровадженої системи кондиціювання повітря, наведені на рисунку 2. Побудова на $I-d-$ діаграмі виконана згідно з [11]. Параметри повітря у характерних точках процесу (рисунок 2) встановлювались за значеннями відповідних параметрів для зовнішнього повітря та підраховувались за відомими аналітичними залежностями для вологого повітря.

Витрату холоду на оброблення повітря у повітроохолоднику (холодопродуктивність повітроохолодника) у ТПР визначали за формулою:

$$
Q_{\mathrm{x}}=G_{\Pi} \cdot\left(I_{3}-I_{\Pi_{1}}\right) \times 0,278, \mathrm{BT},
$$

де $I_{3}$ i $I_{\Pi_{1}}$-питома ентальпія повітря у відповідних точках процесів зміни стану вологого повітря у даній прямотечійній СКП в ТПР на $I-d-$ діаграмі, кДж/кг. 


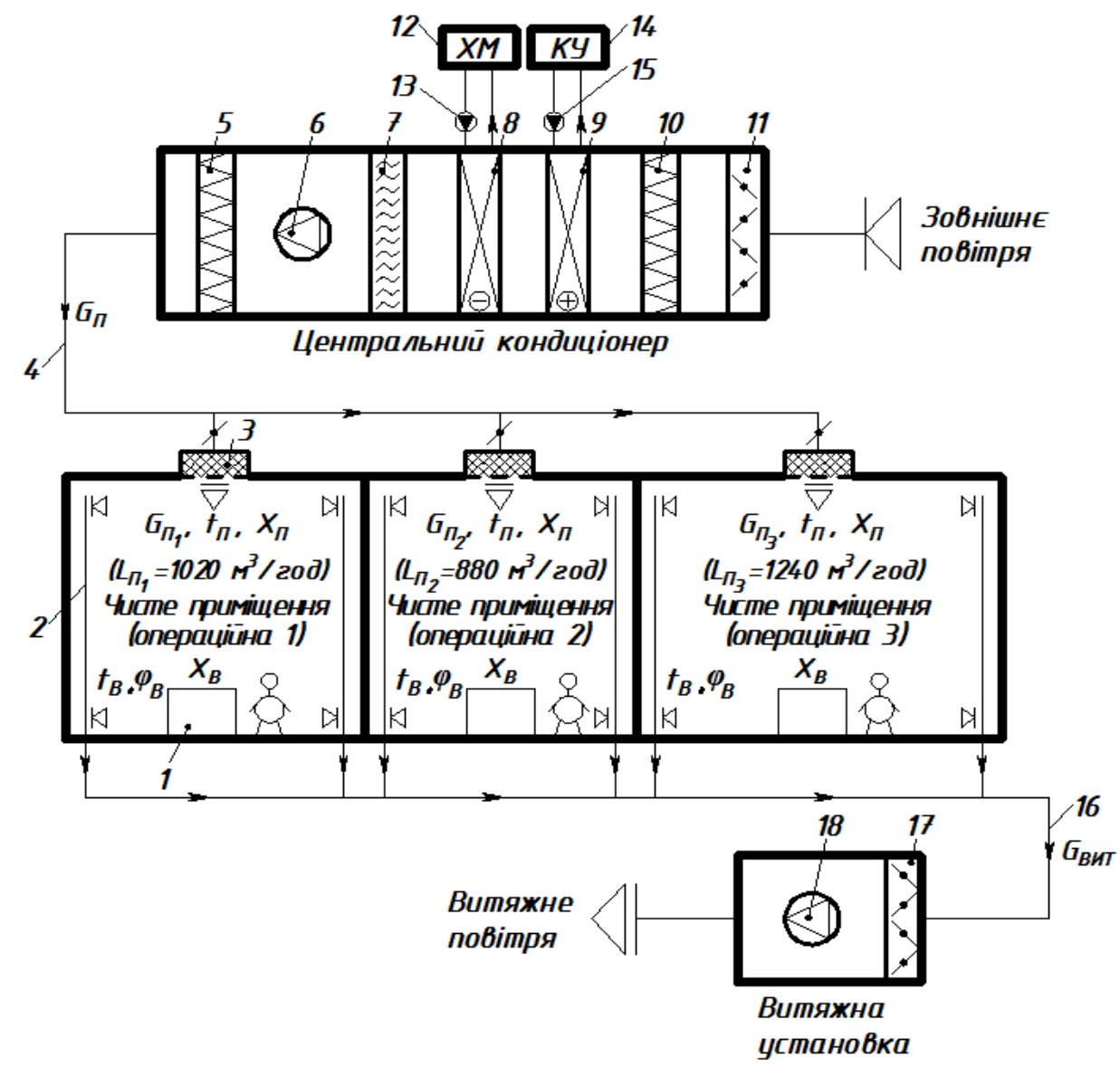

Рисунок 1 - Принциипова схема впровадженої центтральної прямотечійної СКП для операційних чистих кімнат: 1 - технологічне обладнання; 2 - витяжні канали у приміщеннях;

3 - фільтри припливного повітря у приміщення; 4 - припливний повітропровід;

5 - фільтр припливного повітря у кондиціонері; 6-вентиляторний агрегат кондиціонера;

7 - краплевловник кондиціонера; 8 - повітроохолодник кондиціонера;

9 - повітронагрівник кондиціонера; 10 - фільтр зовнішнього повітря у кондиціонері;

11 - клапан зовнішнього повітря у кондичіонері; 12 - холодильна машина ХМ;

13 - насос холодної води ХМ; 14 - котельна установка КУ; 15 - насос гарячої води;

16 - витяжний повітропровід; 17 - клапан витяжного повітря;

18 - вентиляторний агрегат витяжної установки

Завданням даної роботи було провести дослідження ексергоефективності впровадженої прямотечійної системи кондиціювання повітря операційних чистих кімнат, отриманий на ii інноваційній математичній дослідницькій моделі [20] залежно від різних факторів, що впливають на iii роботу, та запропонувати шляхи енергозбереження для цієї СКП. В цій моделі складались матеріальний, тепловий (енергетичний) та ексергетичний баланси даної системи, які враховували всі можливі варіанти іiі роботи в реальних умовах.

Для оцінки ексергоефективності вказаної СКП користувались поняттям ексергетичного ККД, який визначався як відношення приросту ексергії повітря у кондиціонованому приміщенні $E_{\text {вих }}$ до ексергії приводу СКП $E_{\text {вх }}$, яка витрачалась на підтримання процесу [20]:

$$
\eta_{\mathrm{e}}=\frac{E_{\text {вих }}}{E_{\text {вх }}} .
$$

Методика визначення ексергетичного ККД, який характеризує ефективність роботи впровадженої центральної прямотечійної системи кондиціювання операційних чистих кімнат у ТПР, докладно викладена у нашій статті [20].

\section{III. РЕЗУЛЬТАТИ ДОСЛІДНИЦЬКОї РОБОТИ}

Завдяки розрахунково-кількісним експериментам, проведеним на інноваційній математичній дослідницькій моделі описаної центральної прямотечійної системи кондиціювання повітря операційних чистих кімнат, отримані значення ексергетичного ККД $\eta_{\mathrm{e}}$ залежно від різниці 


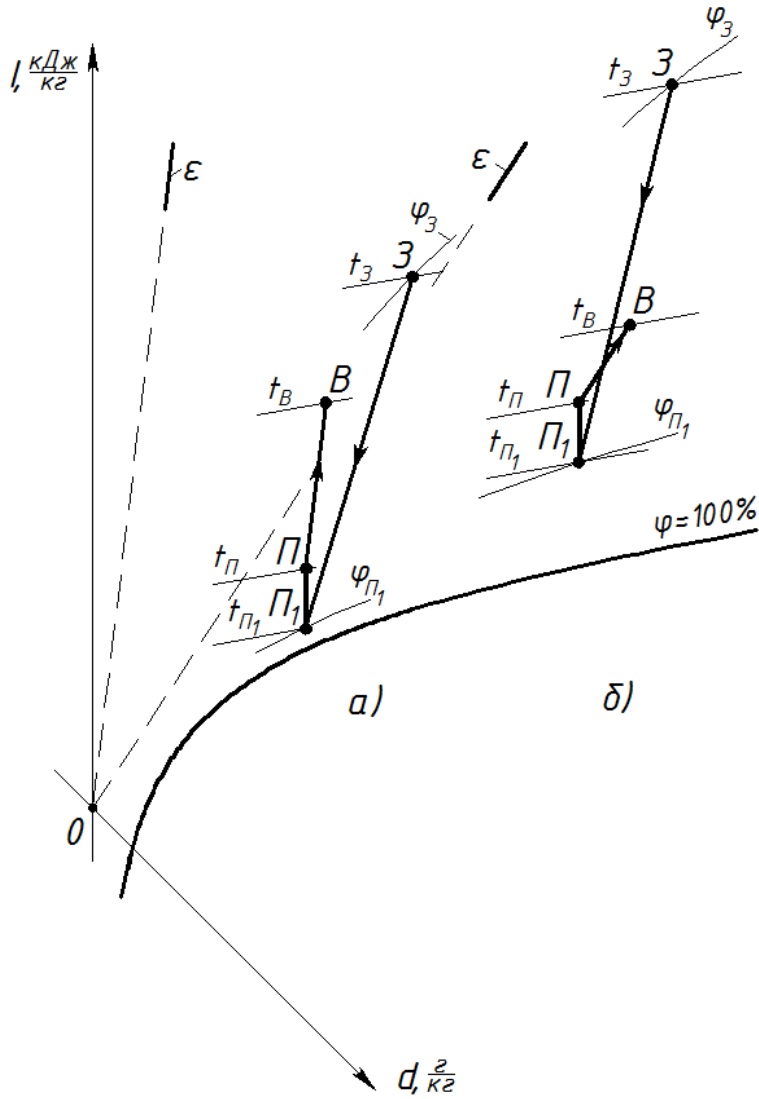

Рисунок 2 - Зображення процесів зміни стану вологого повітря у діючій прямотечійній СКП у ТПР на I-d-діаграмі

a) для умов проведення досліджень $-t_{3}=30$;

$32^{\circ} \mathrm{C} ; t_{\mathrm{B}}=25 ; 26^{\circ} \mathrm{C} ; \Delta t_{\Pi}=9 ; 7^{\circ} \mathrm{C} ;$

б) для умов проведення досліджень $-t_{3}=35$;

$38 ; 40^{\circ} \mathrm{C} ; t_{\mathrm{B}}=27 ; 28 ; 29^{\circ} \mathrm{C} ; \Delta t_{\Pi}=6 ; 5 ; 4^{\circ} \mathrm{C}$ :

$3 \boldsymbol{\Pi}_{1}-$ процес політропного оброблення

(охолодження та осушування) повітря $G_{3}=G_{\Pi}$ у повітроохолоднику;

$\boldsymbol{\Pi}_{\boldsymbol{I}} \boldsymbol{\Pi}$ - прочес підігрівання повітря $G_{\Pi}$ на $1^{\circ} \mathrm{C}$

у вентиляторі та припливному повітропроводі;

ПВ - процес асиміляиії тепло- $i$ вологонадлишків у чистих приміщеннях припливним повітрям $G_{\text {п }}$ кондиціонера

температур між внутрішнім і припливним повітрям $\Delta t_{\Pi}$, температури $t_{\text {в }}$ внутрішнього повітря $\mathrm{i}$ коефіцієнта трансформації $E E R$ холодильної машини, та подані у вигляді відповідних залежностей ексергетичного ККД $\eta_{\mathrm{e}}$ (рисунки 3,4$)$ і на цій основі зроблений аналіз. Разом 3 тим нами було встановлено незначний вплив на ексергетичний ККД $\eta_{\mathrm{e}}$ відносних вологостей зовнішнього $\varphi_{c ̧}$, внутрішнього $\varphi_{\hat{a}}$ i припливного $\varphi_{\ddot{i}}$ повітря (максимально у межах 10\%).

Результати дослідницької роботи кінцево було вирішено подати у вигляді такої узагальненої степеневої залежності:

$$
\eta_{\mathrm{e}}=C \cdot\left(\Delta t_{\text {п }} / t_{\text {в }}\right)^{\alpha} \cdot E E R^{\beta} .
$$

Для отримання показників степеня $\alpha$ i $\beta$ у рівнянні (5) результати досліджень подані нами у вигляді відповідних залежностей на рисунках 3 i 4.

Залежність ексергетичного ККД $\eta_{\mathrm{e}}$ впровадженої центральної прямотечійної системи кондиціювання повітря операційних чистих кімнат від відношення різниці температур між внутрішнім i припливним повітрям до температури внутрішнього повітря $\Delta t_{\Pi} / t_{\text {в }}$ можна подати такою степеневою залежністю:

$$
\eta_{\mathrm{e}}=4,27 \cdot\left(\Delta t_{\Pi} / t_{\mathrm{B}}\right)^{0,53} \text {. }
$$

Максимальна похибка розрахунків за формулою (6) становить $6,0 \%$.

Отже, на основі залежності (рисунок 3, формула (6)) знайдено значення показника степеня $\alpha$, який для нашого випадку становить 0,53.

Аналізуючи отримані дані досліджень на рисунку 3, можна дійти таких висновків. Загальне зростання відношення різниці температур між внутрішнім і припливним повітрям до температури внутрішнього повітря $\Delta t_{\Pi} / t_{\text {в }}$ від 0,14 до 0,36 , тобто в 2,57 рази, призводить до значного зростання значення ексергетичного ККД $\eta_{\mathrm{e}}$ від 1,48 до 2,56 , тобто в 1,73 рази або на $73 \%$. Варто також зауважити (рисунок 3), що найбільше зростання ексергетичного ККД відбувається за різниці температур між внутрішнім і припливним повітрям $\Delta t_{\text {п }}=9,0^{\circ} \mathrm{C}$. Тому 3 метою енергозбереження впроваджену систему кондиціювання повітря потрібно використовувати за вищої різниці температур між внутрішнім і припливним повітрям, a саме, наприклад $\Delta t_{\Pi}=9,0^{\circ} \mathrm{C}$ (за будь-якої температури внутрішнього повітря), що дасть можливість отримати найвищий ексергетичний ККД $\eta_{\mathrm{e}}$, а значить отримати енергоощадний варіант використання впровадженої системи кондиціювання повітря.

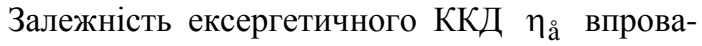
дженої центральної прямотечійної системи кондиціювання повітря чистого приміщення від коефіцієнта трансформації $E E R$ холодильної машини можна подати такою степеневою залежністю:

$$
\eta_{\mathrm{a}}=1,034 \cdot E E R^{0,58} \text {. }
$$

Максимальна похибка розрахунків за формулою (7) становить $0,5 \%$.

Отже, на основі залежності (рисунок 4, формула (7)) знайдено значення показника степеня $\beta$, який для нашого випадку становить 0,58 . 


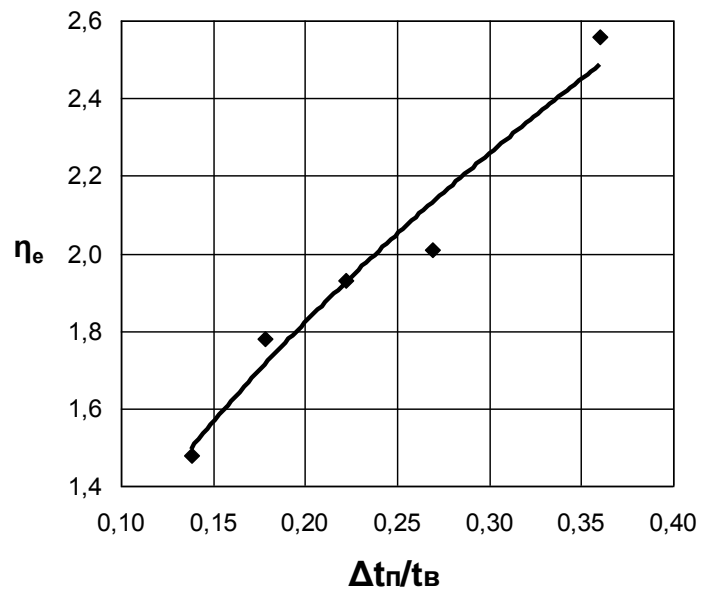

Рисунок 3 - Залежність ексергетичного ККД $\eta_{\mathrm{e}}$ впровадженої иентральної прямотечійної

СКП операчійних чистих кімнат від відношення різниці температур між внутрішнім і припливним повітрям $\Delta t_{\Pi}$ до температури $t_{\mathrm{B}}$ внутрішнього повітря $\Delta t_{\Pi} / t_{\mathrm{B}}$

і умов проведення досліджень:

$G_{\Pi}=4300 \kappa 2 / 2 о д ; \Delta t_{\Pi}=4,0-9,0^{\circ} \mathrm{C}$; $t_{\mathrm{B}}=29-25^{\circ} \mathrm{C} ; E E R=2,574 ; t_{3}=40-30^{\circ} \mathrm{C}$; $\varphi_{\mathrm{B}}=64-54 \% ; \varphi_{3}=36-44 \% ; \varphi_{\Pi}=79-92 \%$

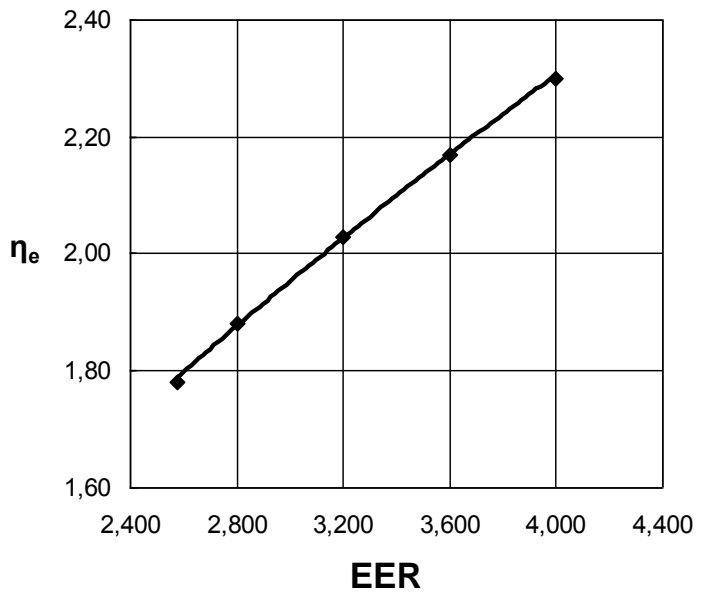

Рисунок 4 - Залежність ексергетичного ККД $\eta_{\mathrm{e}}$ впровадженої иентральної прямотечійної

СКП операчійних чистих кімнат від коефічієнта трансформації EER холодильної машини

і умов проведення досліджень:

$G_{\Pi}=4300 \kappa 2 / 2 о д ; \Delta t_{\Pi}=5,0^{\circ} \mathrm{C}$;

$t_{\mathrm{B}}=28^{\circ} \mathrm{C} ; \Delta t_{\Pi} / t_{\mathrm{B}}=0,18 ; t_{3}=38^{\circ} \mathrm{C}$;

$\varphi_{\mathrm{B}}=64 \% ; \varphi_{3}=38 ; \varphi_{\Pi}=84 \%$

Аналізуючи отримані дані досліджень на рисунку 4, можна дійти таких висновків. Загальне зростання відношення коефіцієнта трансформації $E E R$ холодильної машини від 2,574 до 4,0, тобто в
1,554 рази, призводить до зростання значення ексергетичного ККД $\eta_{\text {̊ }}$ від 1,78 до 2,30, тобто в 1,29 рази або на 29\%. Варто також зауважити (рисунок 4), що найбільше зростання ексергетичного ККД відбувається за коефіцієнта трансформації холодильної машини $E E R=4,0$. Тому 3 метою енергозбереження впроваджену систему кондиціювання повітря бажано використовувати за вищого коефіцієнта трансформації холодильної машини, а саме, наприклад $E E R=4,0$, що дасть можливість отримати вищий ексергетичний ККД $\eta_{a ̊}$, а значить отримати енергоощадний варіант використання впровадженої системи кондиціювання повітря.

Остаточно визначаємо, що коефіцієнт $C=2,53$, та отримуємо узагальнену степеневу залежність для впровадженої центральної прямотечійної системи кондиціювання повітря операційних чистих кімнат:

$$
\eta_{\mathrm{a}}=2,53 \cdot\left(\Delta t_{\mathrm{i}} / t_{\hat{\mathrm{a}}}\right)^{0,53} \cdot E E R^{0,58} .
$$

Максимальна похибка розрахунків за формулою (8) становить 8,7\%.

Значить ексергетичне дослідження впровадженої центральної прямотечійної системи кондиціювання повітря операційних чистих кімнат виконане на створеній авторами інноваційній марематичній дослідницькій моделі дало можливість грунтовно оцінити залежність ексергетичного ККД

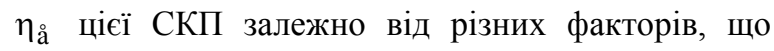
впливають на ії роботу.

\section{IV. ВИСНОВКИ}

Використана авторська інноваційна комп'ютерна дослідницька модель впровадженої центральної прямотечійної системи кондиціювання повітря операційних чистих кімнат, що дала можливість оцінити іiі енергоефективність на основі ексергетичного ККД залежно від різних факторів, що впливають на іiі роботу. Отримано узагальнену степеневу залежність ексергетичного ККД $\eta_{а}$ впровадженої центральної прямотечійної системи кондиціювання повітря операційних чистих кімнат від відношення різниці температур між внутрішнім i припливним повітрям до температури внутрішнього повітря $\Delta t_{\mathrm{i}} / t_{\hat{\mathrm{a}}} \quad$ та коефіцієнта трансформації $E E R$ холодильної машини. Показано, що з метою енергозбереження впроваджену систему кондиціювання повітря бажано використовувати за вищої різниці температур між внутрішнім i припливним повітрям, а саме, наприклад $\Delta t_{\mathrm{i}}=9,0^{\circ} \mathrm{C}$ (за будьякої температури внутрішнього повітря), та за вищого коефіцієнта трансформації холодильної машини, а саме, наприклад $E E R=4,0$, що дасть можливість отримати найвищий ексергетичний ККД $\eta_{a ̊}$, а значить отримати енергоощадний варіант використання впровадженої системи кондиціювання повітря. 


\section{ЛІТЕРАТУРА}

1. Федотов А.Е. Чистые помещения. Второе изд., перераб. и доп. - М.: АСИНКОМ, 2003. - 576 с.

2. Хаякава И. Чистые помещения. Пер. с японск. - М.: Мир, 1990. - 456 с.

3. Уайт В. Технология чистых помещений. Основы проектирования, испытаний и эксплуатации. - М.: Клинрум, 2002. - 304 с.

4. Уайт В. Проектирование чистых помещений. Пер. с англ. - М.: Клинрум, 2004. - 360 с.

5. ГОСТ ИСО 14644-1. Чистые помещения и связанные с ними контролируемые среды. Часть 1. Классификация чистоты воздуха.

6. Соколов Е.Я. Энергетические основы трансформации тепла и процессов охлаждения: учеб. пособие для вузов.- 2-е изд., перераб. / Е.Я. Соколов, В.М. Бродянский. - М.: Энергоиздат, 1981. - $320 \mathrm{c}$.

7. Шаргут Я. Эксергия / Я. Шаргут, Р. Петела. М.: Энергия, 1968. - 280 с.

8. Эксергетические расчеты технических систем: справ. пособие / [В.М. Бродянский, Г.П. Верхивкер, Я.Я. Карчев и др.]; под ред. А.А. Долинского, В.М. Бродянского; Ин-т технической теплофизики АН УССР. - Киев: Наук. думка, 1991. $-360 \mathrm{c}$.

9. Бродянский В.М. Эксергетический метод термодинамического анализа / В.М. Бродянский. М.: Энергия, 1973. - 296 с.

10. Бэр Г.Д. Техническая термодинамика / Г.Д. Бэр. - М.: Мир, 1977. - 518 с.

11. Богословский В.Н. Кондиционирование воздуха и холодоснабжение: Учебник для вузов / В.Н. Богословский, О.Я. Кокорин, Л.В. Петров. Стройиздат, 1985. - 367 с.

12. Прохоров В.И. Метод вычисления эксергии потока влажного воздуха / В.И. Прохоров, С.М. Шилклопер // Холодильная техника. - 1981, № 9. C. 37-41.
13. Шилклопер С.M. Эксергетический анализ систем обеспечения микроклимата и энергоснабжения / С.М. Шилклопер, С.И. Жадин // Строительство и архитектура. Сер. 9. - 1982, вып. 4. - C. $18-27$.

14. СНиП 2.04.05-86. Отопление, вентиляция и кондиционирование. - М.: ЦИТП Госстроя СССР, 1987. -64 c.

15. Янтовский Е.И. Потоки энергии и эксергии / Е.И. Янтовский. - М.: Наука, 1988. - 144 с.

16. Bes T. Egzergia w procesach ogrzewania, klimatyzacji i suszenia / T. Bes // Energetyka Przemysłowa. - 1962. 10, № 11. - S. 388-392.

17. Лабай Володимир. Ексергетична ефективність центральних кондиціонерів / Володимир Лабай, Тарас Іванух // V Konferencja naukowa RzeszowskoLwowsko-Koszycka „Aktualne problemy budownictwa i inżynierii środowiska". Zeszyty naukowe Politechniki Rzeszowskiej «Budownictwo i inżynieria środowiska». - Z. 32, część 2: Inżynieria Środowiska. - Rzeszów: Politechnika Rzeszowska, 25-26 września 2000 r. - S. 229-235.

18. Labay V. Innovation model for energy effective investigations of air conditioning systems for cleanrooms / V. Labay, D. Harasym // ECONTECHMOD - Lublin-Rzeszow: 2014 - Vol. 3, № 1. - P. 47-52.

19. Гарасим Д.І. Оцінювання систем кондиціювання повітря чистих приміщень за діаграмою Грассмана / Гарасим Д.І., Лабай В.Й. // Строительство, материаловедение, машиностроение: Сб. науч. трудов. Вып. № 76. - Дн-вск: ПГАСА, 2014. - С. 95-100.

20. Лабай В.Й. Залежність ексергетичного ККД системи кондиціювання повітря операційних чистих кімнат від коефіцієнта трансформації холодильної машини / В.Й. Лабай, Д.І. Гарасим // Науковотехнічний журнал «Холодильна техніка і технологія», т. 51, вип. 3. - Одеса: ОНАХТ, 2015. C. 14-21.

Отримана в редакції 11.06.2015, прийнята до друку 03.07.2015

\section{V.Y. Labay ${ }^{\bowtie}$, D.I. Harasym}

Lviv Polytechnic National University, 12 St. Bandery str., Lviv, 79013, Ukraine

$\triangle$ e-mail: wlabay@i.ua

\section{INVESTIGATIONS OF EXERGY EFFECTIVENESS AND WAYS OF ENERGY SAVING OF AIR CONDITIONING SYSTEM FOR OPERATING CLEANROOMS}

Nowadays for Ukraine the problem with saving energy resources is especially relevant in a conditions of market economy, where the main energy carriers, such as oil and gas, are limited. That's why in the last decade with the aim of saving energy resources the fundamental researches of activity of different branches, manufactures and technologies from positions of exergy methodology are held abroad. Today cost estimates can't be the only measure of effectiveness of energy equipment which recycles energy resources. Exergy is physical, not economical criterion and determines independence of this parameter from price fluctuations. The application of exergy allows to give objective assessment of energy resources of any type as it is the only measure of working capacity, applicability of energy resources. There are many examples of successful application of exergy methodology by technical and economical 
optimization in industry, especially in energy intensive branches. The minimum should be determined by exergy losses per unit of provided heat, not by financial costs. The analysis of exergy effectiveness of implemented central straight flow air conditioning system (ACS) for operating cleanrooms which was obtained on its innovative mathematical research model depending on different factors that have influence on its work was presented in this article, and ways of energy saving for this ACS was proposed. It was found that the biggest impact on exergy output-input ratio of its air conditioning system have the temperature difference between inside and supplied air in a room, temperature of inside air which is depends on temperature of outside air, and coefficient of transformation EER of chosen refrigeration machine of air conditioning system. It was shown that with the aim of energy saving the implemented air conditioning system should be preferably used at a higher temperature difference between inside and supplied air, for example, $\Delta t_{\mathrm{S}}=9,0^{\circ} \mathrm{C}$ (at any temperature of inside air) and at higher coefficient of transformation, for example EER $=4,0$, which gives the opportunity to get the highest exergy output-input ratio $\eta_{a}$, which means to get the most energy saving variant of exploitation of implemented air conditioning system.

Key words: Air conditioning systems; Cleanrooms; Exergy balance; Exergy effectiveness; Energy saving

\section{REFERENCES}

1. Fedotov A.E. 2003. Chistye pomeshcheniia. Vtoroe izd., pererab. i dop. - Moskva: ASINKOM, 2003. - 576 (in Russian).

2. Hayakava I. 1990. Chistye pomeshcheniia. Per. s iaponsk. - Moskva: Mir. - 456 (in Russian).

3. Whyte W. 2002. Tekhnologiia chistykh pomeshchenii. Osnovy proektirovaniia, ispytanii i ekspluatatsii. - Moskva: Klinrum. - 304 (in Russian).

4. Whyte W. 2004. Proektirovanie chistykh pomeshchenii. Per. s angl. - Moskva: Klinrum. - 360 (in Russian).

5. GOST ISO 14644-1. Chistye pomeshcheniia i sviazannye s nimi kontroliruemye sredy. Chast' 1. Klassifikatsiia chistoty vozdukha (in Russian).

6. Sokolov E.Ia. 1981. Energeticheskie osnovy transformatsii tepla i protsessov okhlazhde-niia: ucheb. posobie dlia vuzov. - 2-e izd., pererab. / E.Ia. Sokolov, V.M. Brodianskii. - Moskva: Energoizdat. 320 (in Russian).

7. Shargut Ia. 1968. Eksergiia / Ia. Shargut, R. Petela. - Moskva: Energiia. - 280 (in Russian).

8. Eksergeticheskie raschety tekhnicheskikh sistem. 1991: sprav. posobie / [V.M. Brodianskii, G.P. Verhivker, Ia.Ia. Karchev i dr.]; pod red. A.A. Dolinskogo, V.M. Brodianskogo; In-t tekhnicheskoi teplofiziki AN USSR. - Kiev: Nauk. dumka. - 360.

9. Brodianskii V.M. 1973. Eksergeticheskii metod termodinamicheskogo analiza / V.M. Brodianskii. Moskva: Energiia. - 296 (in Russian).

10. Ber G.D. 1977. Tekhnicheskaia termodinamika / G.D. Ber. - Moskva: Mir. - 518 (in Russian).

11. Bogoslovskii V.N. 1985. Konditsionirovanie vozdukha i kholodosnabzhenie: Uchebnik dlia vuzov / V.N. Bogoslovskii, O.Ia. Kokorin, L.V. Petrov. Stroiizdat. - 367 (in Russian).

12. Prokhorov V.I. 1981. Metod vychisleniia eksergii potoka vlazhnogo vozdukha / V.I. Prokhorov, S.M. Shilkloper // Kholodil'naia tekhnika. - № 9. - 37-41 (in Russian).

13. Shilkloper S.M. 1982. Eksergeticheskii analiz sistem obespecheniia mikroklimata i energosnabzhe- niia / S.M. Shilkloper, S.I. Zhadin // Stroitel'stvo i arkhitektura. Ser. 9. - Vyp. 4. - 18-27 (in Russian).

14. SNiP 2.04.05-86. 1987. Otoplenie, ventiliatsiia i konditsionirovanie. - Moskva: TsITP Gosstroia SSSR. - 64 (in Russian).

15. Iantovskii E.I. 1988. Potoki energii i eksergii / E.I. Iantovskii. - Moskva: Nauka. - 144 (in Russian).

16. Bes T. 1962. Egzergia w procesach ogrzewania, klimatyzacji i suszenia / T. Bes // Energetyka Przemysłowa. - 10, № 11. - 388-392 (in Polish).

17. Labai Volodymyr. 2000. Eksergetychna efektyvnist' tsentral'nykh kondytsioneriv / Volodymyr Labai, Taras Ivanukh // V Konferencja naukowa Rzeszowsko-Lwowsko-Koszycka „Aktualne problemy budownictwa i inżynierii środowiska”. Zeszyty naukowe Politechniki Rzeszowskiej «Budownictwo i inżynieria środowiska». - Z. 32, część 2: Inżynieria Środowiska. - Rzeszów: Politechnika Rzeszowska, 25-26 września. - 229-235 (in Ukrainian).

18. Labay V. 2014. Innovation model for energy effective investigations of air conditioning systems for cleanrooms / V. Labay, D. Harasym // ECONTECHMOD - Lublin-Rzeszow: 2014 - Vol. 3, № 1. - 47-52 (in English).

19. Garasym D.I. 2014. Otsiniuvannia system kondytsiiuvannia povitria chystykh prymishchen' za diagramoiu Grassmana / Garasym D.I., Labay V.I. // Stroitel'stvo, materialovedenie, mashynovedenie: Sb. nauch. trudov. Vyp. № 76. - Dn-vsk: PGASA. - 95100 (in Ukrainian).

20. Labai V.I. 2015. Zalezhnist' eksergetychnogo KKD systemy kondytsiiuvannia povitria operatsiinykh chystykh kimnat vid koefitsiienta transformatsii kholodyl'noi mashyny / V.I. Labai, D.I. Garasym // Naukovo-tekhnichnykh zhurnal «kholodyl'na tekhnika i tekhnologiia», т. 51, vyp. 3. - Odesa: ONAKHT. 14-21 (in Ukrainian).

Received 11 June 2015 Approved 03 July 2015 Available in Internet 30.08.2015 